\title{
Lupus Anticoagulant Antibody
}

National Cancer Institute

\section{Source}

National Cancer Institute. Lupus Anticoagulant Antibody. NCI Thesaurus. Code C70620.

Antibodies directed ag ainst plasma proteins (such as beta-2-glycoprotein I, prothrombin, or annexin V) bound to anionic phospholipids. The anticoagulant blocks in vitro assembly of the prothrombinase complex, resulting in prolongation of in vitro clotting assays such as the activated partial thromboplastin time, the Russell viper venom time, and others. Paradoxical to these changes which suggest impaired coagulation, patients with the lupus anticoagulant have an increase in thrombotic events. 